\title{
Luovuus tutkimuksen tekemisen ja maailman ymmärtämisen tapana
}

Ryynänen, Sanna \& Rannikko, Anni (toim.) (2021). Tutkiva mielikuvitus. Luovat, osallistuvat ja toiminnalliset tutkimusmenetelmät yhteiskuntatieteissä. Gaudeamus. 328 sivua.

TUTKIVA MIELIKUVITUS kokoaa yhteen tutkimusmenetelmiä, joilla pyritään laajentamaan tiedon ja tietämisen kirjoa yhteiskuntatieteissä. Pontimena luoville, osallistuville ja toiminnallisille tutkimusmenetelmille on tarve tavoittaa ihmisenä olemisesta ja ympäröivästä maailmasta jotain sellaista, mitä perinteisemmät menetelmät eivät tavoita. Pyrkimyksenä on myös löytää yhä tasa-arvoisempia ja yhteistoiminnallisempia tutkimisen tapoja, jotka madaltavat tutkijan ja tutkimukseen osallistuvien välisiä valtahierarkioita.

Teos on tarkoitettu oppikirjaksi. Se on suunnattu yhteiskunta-, sosiaali- ja kasvatustieteiden sekä taidealojen opiskelijoille, tutkimustyön ammattilaisille ja tutkimusmenetelmiä opettaville. Lisäksi teoksen lukijoiksi nähdään laajasti kaikki, joita kiinnostaa luova tutkimuksellinen ote yhteiskuntaan ja sen ilmiöihin. Itse lukeudun viimeiseen lukijakuntaan.

\section{TIETÄMISEN KIRJO LAAJENEE}

Teos luo yhtenäisen ja samalla riemastuttavan monipuolisen kokonaisuuden. Se avaa hienoja näkymiä tutkimusmenetelmiin, joiden pyrkimyksenä on laajentaa tiedon ja tietämisen kirjoa. Järjen käytön, rationaalisen ajattelun ja pelkän kielellisen ilmaisun rinnalle nostetaan tunteita, kokemuksia, mielikuvitusta ja kehollisuutta hyödyntäviä tutkimusmenetelmiä.

Artikkelit jäsentyvät kolmeksi kokonaisuudeksi. Ensimmäisessä osassa keskitytään asioihin, joita ei perinteisesti ole nähty yhteiskuntatieteellisesti merkityksellisiksi. Juha Suoranta ja Olli Pyyhtinen kääntävät katseemme kaunokirjallisuuteen yhteiskuntatutkimuksessa, Anni Rannikko ja Pertti Rannikko puolestaan autoetnografian hyödyntämiseen vaikenemisen kulttuurien tutkimuksessa. Eemeli Hakoköngäs ja Jari Martikainen kuvaavat visuaalisten menetelmien käyttöä arkiajattelun tutkimuksessa.

Toinen osa kutsuu kuvittelemaan: Kaarina Mönkkösen eläytymismenetelmää avaava artikkeli sekä Vilma Hännisen ja kollegoiden "Kirje tulevaisuudesta" -menetelmään pureutuva artikkeli tarjoavat käytännön esimerkkejä keinoista tavoittaa tarinallisuudella asioita, joita ei voi tarkastella vain jo koetun tai nykyhetken näkökulmista. Johanna Hohenthalin artikkeli osallistuvasta kartoituksesta tutkimusmenetelmänä taas valottaa keinoja tavoittaa yhdessä ei-sanallistettavaa, spatiaalista tutkimustietoa paikallisyhteisöjen näkökulmasta.

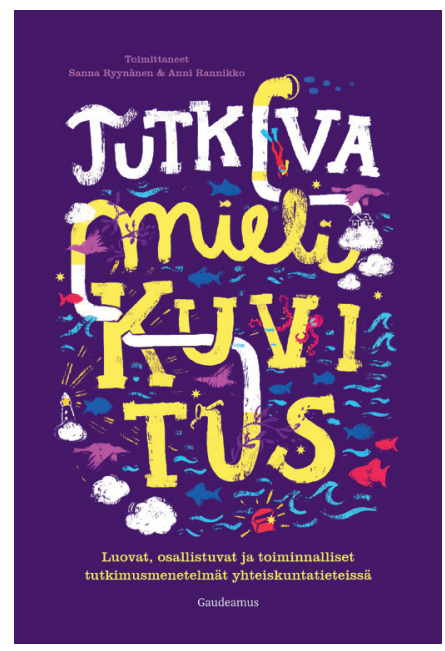

TUTKIMUS

YHTEISKUNNALLISENA TOIMINTANA

Kirjan kolmannessa osassa suunnataan yhdessä kohti toimintaa soveltavan teatterin, muistelutyömenetelmän ja aktivistitutkimuksen yhden tutkimusmenetelmän, kuljeskelun, avulla. Kaikki menetelmät perustuvat siihen, että tutkija on yksi osallistuja muiden rinnalla muisteluryhmässä, kollektiivissa tai aktivistina.

Soveltavan teatterin artikkelin kirjoittajat Sanna Ryynänen, Emma Nortio ja Sirkku Varjonen kuuluvat Puhekupla-työryhmään, joka järjestää soveltavaan teatteriin pohjautuvia maahanmuuttoteemaisia tilaisuuksia baareissa, kirjastoissa ja palvelutaloissa. Osallistavalla teatterilla synnytetään dialogia aiheesta, joka jakaa voimakkaasti mielipiteitä. Samalla se on tapa tuottaa tutkimustietoa.

Muistelutyömenetelmä taas on feministinen tutkimuksen tekemisen tapa, jossa valtavirtatieteen numeerinen, mitattava ja 
neutraali "fakta" haastetaan: muistot, kokemukset ja tunteet nähdään arvokkaana ja vakavasti otettuna tietona. Kuten Mari Käyhkö toteaa: "Muistelutyössä hyödynnetään kaikkea sitä, mitä patriarkaalisessa tieteessä on pidetty tiedettä likaavana. Muistelutyömenetelmä häiritsee, kyseenalaistaa, venyttää ja purkaa akateemisen maailman tapoja tehdä tutkimusta, vaikka ne ovatkin murentuneet ja monentuneet sitten muistelutyön syntyaikojen." (s. 239)

Kirjan päättää artikkeli kuljeskelusta aktivismitutkimuksena. Tiina Sotkasiira, Anni Rannikko, Päivikki Rapo ja Sanna Ryynänen kuvaavat kuljeskelua osana taistelevan ja aktivistitutkimuksen perinnettä. Tieto tuotetaan yhdessä: aktivisteiksi identifioituvat tutkijat lähtevät liikkeelle tavoitteenaan tuoda näkyväksi vallankäyttöä valitusta teemasta. Kuljeskelukumppaneiksi - oppaiksi - pyydetään aihetta omakohtaisesti tuntevia. Kuljeskelu on samalla "politiikan tekemisen alkuainetta" (s. 243) ja yhteisen vastarinnan väline: tutkijat ovat mukana liikkeessä, joka haluaa vaikuttaa epäkohtiin ja hakee muutosta, kuten yhteiskunnallista oikeudenmukaisuutta tai ekologista vastuuta.

\section{MUUTOS JA YHTEYS OPPIMISEEN}

Teos toimii erinomaisesti opiskelijan perusteoksena. Vapaan sivistystyön toimija löytää kirjasta monia omaan työhönsä resonoivia asioita. Luovuus, osallistuminen ja toiminta ovat lähtökohtina kirjassa esitellyissä tutkimusmenetelmissä.
Samat teemat voi liittää vahvasti oppimiseen, sivistymisen prosessiin sekä kansalaisuuteen ja toimijuuteen. Kun kirjoittajat yhdistävät yhteiskuntatieteellisen tutkimuksen ja taideperustaisuuden, omassa työyhteisössäni taidelähtöisyys liitetään oppimiseen ja kansalaistoimintaan.

Tutkimusmenetelmät resonoivat muun muassa uudistavan ja kokemuksellisen oppimisen sekä kriittisen pedagogiikan teemoihin. Esimerkiksi kuljeskelun ja osallistavan teatterin ominaisuuksilla - tietämisen kehollisuudella, havainnollistavuudella ja kokonaisvaltaisuudella, dialogisuudella ja yhteistoiminnallisuudella, tutkijoiden ja taiteilijoiden yhteistyöllä sekä muutoksen tavoittelulla - on valtava potentiaali paitsi yhteiskunnalliselle tutkimuksenteolle myös transformatiivisen, uudistavan oppimisen tukemiselle (vrt. esim. Laininen 2018). Samoin "Kirjeitä tulevaisuudesta" -menetelmällä on yhtymäkohta transformatiiviseen oppimiseen: "Tulevaisuuteen suuntautumisen merkitystä sosiaalitieteissä on korostettu sanomalla, että maailman kuvaamisen sijaan niiden tulisi yhä enemmän osallistua tulevaisuuden maailman rakentamiseen" (s. 135). Vastaavasti osallistuva kartoitus tutkimusmenetelmänä voidaan suhteuttaa paikallistoiminnan yhteiskehittämisen ja yhteistoiminnallisen oppimisen työkaluihin.

Transformatiivinen oppiminen edellyttää mahdollisten tulevaisuuksien kuvittelua, luovuutta, mielikuvitusta ja toimintaa.
Uudistavaa oppimista voidaan tukea hyödyntämällä kirjassa esiteltyjä tietämisen ja tuntemisen tapoja - kehollisuutta, tunteita, tarinoita, visuaalisuutta, muistoja ja mielikuvitusta. Iloitsen siitä, että yhteiskuntatieteellisessäkin tutkimuksessa on käytössä tutkiva mielikuvitus ja siitä ammentavat tutkimusmenetelmät. Niitä Tutkiva mielikuvitus esittelee selkeästi ja mukaansatempaavasti. Teoksen toivoisi tulevan osaksi kaikkien yhteiskunta-, sosiaali- ja kasvatustieteiden sekä taidealan opiskelijoiden peruslukemistoa.

\section{ANNELIINA WEVELSIEP}

YTM, pääsihteeri

Sivistysliitto ja Opintokeskus

Kansalaisfoorumi

\section{LISÄÄ AIHEESTA:}

Laininen, E. (2018).

Transformatiivinen oppiminen ekososiaalisen sivistymisen mahdollistajana. Ammattikasvatuksen aikakauskirja, 2(5), 16-38. https://akakk.fi/ ammattikasvatuksen-aikakauskirja05-2018-digitaalinenerikoisnumero 